\title{
Ellipsis
}

2015

\section{The Motherly Sorceress: Frau Gothel as a Non-Villainous Mother- Figure}

Jessica D'Aquin

University of New Orleans

Follow this and additional works at: https://scholarworks.uno.edu/ellipsis

\section{Recommended Citation}

D'Aquin, Jessica (2015) "The Motherly Sorceress: Frau Gothel as a Non-Villainous Mother-Figure," Ellipsis: Vol. 42 , Article 24.

DOI: https://doi.org/10.46428/ejail.42.24

Available at: https://scholarworks.uno.edu/ellipsis/vol42/iss1/24

This Literary Criticism is brought to you for free and open access by the Department of English and Foreign Languages at ScholarWorks@UNO. It has been accepted for inclusion in Ellipsis by an authorized editor of ScholarWorks@UNO.For more information, please contact scholarworks@uno.edu. 


\title{
The Motherly Sorceress: Frau Gothel as a Non-Villainous Mother-Figure
}

\author{
Jessica D’Aquin
}

Catherine Barragy Mackin Memorial Prize Winner

When Jacob and Wilhelm Grimm first published the story of "Rapunzel" in 1812 within their collection Kinder- und Hausmärchen, Frau Gothel, the woman we now know to be the witch who locks Rapunzel in the tower, was originally written using the German word for "fairy." A few years later, when Wilhelm Grimm heavily edited the tales for stylistic continuity and censoring, Frau Gothel was instead described with the German word for sorceress: "Zauberin." This word and its connotations are very different from "Hexe," the German word for witch. Despite the fact that the Grimms never claimed she was a witch, translations into English referred to Frau Gothel as a witch rather than a sorceress, perhaps in an attempt to cast her in a more negative light than the Grimms seemed willing to use. This discrepancy between the more positive original German "Zauberin" and the more negative English translation to "witch" makes Frau Gothel a very complex, but not evil, mother-figure in "Rapunzel." It is incorrect to call Frau Gothel by the more negative term "witch," and she should be referred to as the motherly, caring sorceress that the Grimms actually wrote her as in the original German tale.

In early modern Europe, a period which spanned from about the late $15^{\text {th }}$ century to the late $18^{\text {th }}$ century, citizens across the continent knew quite a lot of stories about men and women who had been accused of witchcraft. However, much unlike those in the Kinder- und Hausmärchen, these stories were true. According to Elizabeth Cohen, a historian who has written about the marginalized women of the early modern period, European tribunals prosecuted tens of thousands of witches, many of whom were executed, during the highpoint of the witch-hunts between the years 1560 and 1660 (326). These were their neighbors, their family members, their friends who were being accused of using dark magic under the enlistment of Satan. This crazed attack on witchcraft that swept over Europe did not leave it unmarred; the culture of lower class and rural people was affected heavily in this time. Many of the oral tales that were carried on from this time and into the 1800 s described witches, always placing them in the category of villains. 
In one very common Grimm fairy tale, "Hansel and Gretel," the siblings are thrown out of their home because their parents lack the means to feed them. They are abandoned in woods, whereupon they encounter the home of a witch. This witch is a perfect example of how negative the connotations towards witchcraft were in the 1800s and before. In the original German version, the word "Hexe," which directly translates to "witch," is used. This word is used to paint the woman as the inherently evil villain. This witch is a temptress, building her home out of bread and sweets to lure children into her den so that she might eat them. She is given red eyes by the Grimms, a physical manifestation of her deal with the devil. She is by no means a character with which the reader can be sympathetic. She is given the word "Hexe" to mark her as an evil woman who is out to harm other people. There is a significant difference between the connotations associated with the words "sorceress" and "witch," one which can be brought to light with closer inspection.

Historically and culturally, the witch-hunts put a large strain on traditions that some Europeans had been following for centuries. In its original sense, before any connotations of Satan arose, magic was an otherworldly force that most cultures sought out for aid. Paganism was not uncommon in Germany before the Reformation, and a lot of folk religions focused on naturalistic magic. Those who practiced magic were usually considered wise and respected because they were seen as benefactors to society. They were the healers in a world that knew little about medicine, their knowledge of herbs and remedies irreplaceable. According to - ironically male - historians, magic was not something practiced by women, as it was unseemly in many cultures for a woman to do rituals (Raglan 124). However, something shifted during the Reformation years when Christianity and Protestantism took rise; women became the ones who were primarily labeled practitioners of magic. Healing is considered a nurturing and feminine task, and perhaps this had a hand in the stereotype. However, it is much more likely that this gendered change in responsibility was an attempt at scapegoating.

When organized religion started growing in popularity across Europe, those who practiced magic were labeled witches. Seeking out these witches for the aid they offered was "dangerous in the Reformation years, especially after both Catholic and Protestant theorists recast witchcraft as heresy" (Cohen 326). That is not to say that those who practiced magic were the only ones to be accused of witchcraft; much the opposite, the act of accusing someone of witchcraft was more likely to be based on scapegoating those, particularly marginalized women, who were "old, infertile, poor, ugly, and ill-tempered" (Cohen 326). These were the women society wanted nothing to do with and wanted swept under the rug with a convenient hanging or burning. The religious theorists claimed that these women had made a deal with the devil and used black magic to harm others in Satan's name. Rumors of naked dancing in the forest and the eating of babies 
were spread. Thus witchcraft became synonymous with devil-worship. This façade covered up a culling of women on the margins of society.

However, the Grimm brothers refused to label Frau Gothel a witch; "witch" is the word one ascribed to an undesirable, to a pariah of society. Instead, she is given the more respectable title of sorceress. This could potentially be a residual sentimentality for old world magic and its beneficence to society, left over from those oral storytellers who struggled with the new ideals of the Reformation. A sorceress seems to evoke a less threatening, less ugly power. A sorceress, while still a woman with magic, does not pose the same threat as someone who has aligned herself with the devil. Though Frau Gothel is certainly a woman on the margins of society, she is self-sustaining and without a man in her life to provide for her, not to mention the fact that she has a magic garden. The Grimms are unwilling to stigmatize her for it. Indeed, it seems almost obvious that Frau Gothel should not be considered the "evil witch" the English translators painted her as at all. For example, her bountiful garden provides a cure for her pregnant neighbor's cravings: "Her craving for [rapunzel] grew day to day, and she began to waste away because she knew she would never get any" (Grimm 154). In old wives tales of the past, it was said that women who did not satisfy their pregnancy cravings would suffer from bad luck, miscarriages, or even death, so when the husband sees that his wife has become "so pale and wretched," he is willing to do anything to help her survive (Grimm 154). Frau Gothel here takes on the role of healer and medicine-woman, much in the way those who practiced magic in a positive way before the early modern period did, justifying her denotation as "sorceress" rather than "witch."

There is the concern with Frau Gothel's morality in the scene in which she takes her neighbors' child. It may seem odd that Frau Gothel asks for the unborn child in return for the rapunzel the husband steals, but when considered closely, she is asking for equal trade. Should the wife not receive this rapunzel, she may die. Frau Gothel owns the only thing that will help the woman and is asking that, to save the woman's life, Frau Gothel should receive a life in payment: the child. In fact, if anyone should be questioned morally in this situation, it should be the husband. The husband is so desperate to save his own life when Frau Gothel catches him in her garden that he is willing to give anything. So when Frau Gothel asks if he is willing to give up his unborn child in return for his life and the rapunzel he stole, he agrees because of his fear of death. Rather than risk himself to protect his daughter from someone he fears, he throws the child at Frau Gothel readily. With a promise to protect the child as though she were her mother, the sorceress takes the girl away from her parents. Frau Gothel does nothing wrong by taking Rapunzel from her parents, and she is not labelled a villain for it.

It should also be considered that the Grimm brothers refused to paint Frau Gothel as a classic fairy tale villain. Whereas the rest of the witches, as well as 
villainous mother-figures in general, depicted in their fairy tales are punished in horrible and cruel ways, Frau Gothel disappears from the tale entirely, skipping out on a classic punishment scene. The witch of "Hansel and Gretel" is punished rather grievously for her crime; she is thrown into an oven and burned to death - a scene which seems eerily reminiscent of witch burnings. Similarly, the motherfigure of the Grimms' "Snow White" is punished in a disturbing scene in which she must dance herself to death in a pair of red-hot iron shoes. That Frau Gothel is called a sorceress seems especially important when reflecting on this lack of punishment. She does not use her powers to lure and eat children like the witch of "Hansel and Gretel," nor does she harm her daughter because of the girl's beauty like the mother of "Snow White." If Frau Gothel was a simple witch or overbearing mother-figure, she would certainly be a villain; however, as it stands, the sorceress is someone with whom the audience can sympathize.

We receive no indication that Rapunzel is treated poorly by Frau Gothel, and she seems to keep her promise to "care for [her] like a mother" would (Grimm 154). In fact, the act of locking Rapunzel in the tower seems a very motherly and protective thing to do. Frau Gothel takes her adoptive daughter to the tower when she reaches the age of twelve, an age which marks Rapunzel's sexual maturity. This sexual maturity becomes clear when looking at the original German version of the tale. In the Grimm tales, female children below the age of twelve are almost always referred to with gender neutral pronouns, and the shift from neutral pronouns to feminine pronouns denote the change from child to woman (Robinson 110). Immediately after Rapunzel reaches twelve, the pronouns change from the German neuter "es" to the feminine "sie," meaning that Frau Gothel now has to worry about men coming to take away her adoptive daughter. Frau Gothel seems to want to protect Rapunzel from the evils and pains of the world; being a woman unattached to a man, she likely wants to keep Rapunzel similarly unattached.

For Frau Gothel, the tower means freedom from this, while for Rapunzel it means imprisonment. The sorceress tries to protect the one she loves and end up smothering the girl in the process, which leads to Rapunzel's inevitable betrayal. In the face of this betrayal, Frau Gothel abandons Rapunzel in the desert, hurt by the fact that her daughter has tried to replace her love with that of the prince. Though her act of locking the girl away is selfish, she does them with the intent of protecting Rapunzel from the unknown. She does not leave Rapunzel in the desert to hurt her; rather, she wants Rapunzel to learn a lesson about growing up. This is not an evil act on her part, but rather a very motherly act. The desert here represents the real world which Frau Gothel originally sheltered Rapunzel from. Many parents understand that, for the young person to learn how to be an adult, they must force their children out into the real world, which is harsh and 
terrifying. The abandonment in the desert is therefore not the villainous act of a witch, but the act of a motherly sorceress who wants her adoptive child to grow.

The Grimm brothers never wrote in a punishment for the selfish actions of Frau Gothel, not even in the 1812 version when she is described as a wicked fairy. Their unwillingness to label Frau Gothel as a witch, and thus a villain, seems to stem from the sympathetic nature of her story. Rather than the more negative and evil word "Hexe," she is given the word "Zauberin" to show that she is not a villain. The English mistranslation does not fully represent the complexity of her motherly and magical character. It is obvious the woman is a person on the margins of society, much like those who were labelled witches during the Reformation. However, the presence of that marginality does not mar her as a witch. Instead, the Grimms allow Frau Gothel to be a healer, a mother, a sorceress. 
Works Cited

Cohen, Elizabeth S. "Women on the Margins." The Ashgate Research Companion to Women and Gender in Early Modern Europe. Eds. Alyson M. Poska, Jane Couchman, and Katherine A. McIver. Surrey: Ashgate Publishing Limited, 2013. 317-339. Web. April 122014.

Grimm, Jacob and Wilhelm. "Rapunzel." Folk \& Fairy Tales. 3rd ed. Eds. Martin Hallet and Barbara Karasek. Ontario: Broadview Press, 2009. 154-156. Print.

Raglan, Lord. "Magic and Religion.” Folklore. 50.2 (1939): 115-136. JSTOR. Web. 4 May 2014.

Robinson, Orrin W. "Does Sex Breed Gender? Pronominal Reference in the Grimm's Fairy Tales.” Marvels \& Tales. 21.1 (2007): 107-121. Project MUSE. Web. 15 Mar. 2014. 